Purkayastha, N.N., \& Tuzlukaya, S..E. (2020). Determination of the benefits and risks of Peer-toPeer (P2P) lending: a social network theory approach. Copernican Journal of Finance \& Accounting, 9(3), 131-143. http://dx.doi.org/10.12775/CJFA.2020.016

\author{
Nadia Nahar Purkayastha* \\ Atılım University \\ Şule Erdem Tuzlukaya** \\ Atılım University
}

\title{
DETERMINATION OF THE BENEFITS AND RISKS OF PEER-TO-PEER (P2P) LENDING: \\ A SOCIAL NETWORK THEORY APPROACH
}

Keywords: P2P, social networks, trust, perceived risk, security, developing country.

J E L Classification: G21, G28, D85, L31, B55.

Abstract: Peer-to-Peer lending which is also known as P2P is an online financial investment platform where individual investors finance projects by lending money to individual borrowers through social networks. P2P models usually contributing to less privileged people especially entrepreneurs and frontier groups who do not have access to formal financial services. However, due to the economic conditions and lack of government support, P2P lending platforms in developing countries often fail to reveal the 'credit history' and 'indebtedness' of individual borrowers which have an expressive impact on loan performance. The objective of this study is to demonstrate theoretically the factors those influence the lenders to participate in the P2P lending platform in

Date of submission: August 12, 2020; date of acceptance: October 4, 2020.

* Contact information: nadiapurkayastha@gmail.com, Atılım University, Social Sciences Institute, MBA Program, Incek, Ankara, Turkey, phone: +90 5060934959, ORCID ID: https://orcid.org/0000-0002-8072-5508.

** Contact information: sule.tuzlukaya@atilim.edu.tr, Atılım University, Faculty of Management, Department of Management, Incek, Ankara, Turkey, phone: +90 312 5868612; ORCID ID: https://orcid.org/0000-0001-8244-6396. 
developing countries and the associated risks. For this purpose, two propositions are developed to examine the factors to demonstrate the role of the social network is also combined to further explain the P2P lending.

\section{IIIITRODUCTION}

Peer-to-Peer (P2P) lending is a type of online financial investment platform where individual investors finance projects by lending money to projects or such individual borrowers as entrepreneurs (Du, Li, Lu \& Lu, 2020; Ariza, Arroyo, Caparrini \& Segovia, 2020; Balyuk, 2019). Internet-based P2P lending, empowers individuals to acquire loans directly from other individuals, therefore may eliminate the financial institution as the intermediary thus, offer larger admittance to credit opportunity at a lower cost. In the case of Small and Medium-sized Enterprises (SMEs), such web-based emerging lending platforms assist microfinance as an alternative method of financing or investing (Chen, Chong \& Giudici, 2020; Paravisini, Rappoport \& Ravina, 2017; Iyer, Khwaja, Luttmer \& Shue, 2016). Through the P2P lending platform interested borrowers can place a request for loans to the web-based platform and they can be founded by exclusive lenders directly or indirectly (Everett, 2019; Bachmann, Becker, Buerckner, Hilker, Kock, Lehmann, Tiburtius \& Funk, 2011).

Although without the existence of mediators it is very difficult for P2P platforms to obtain credit history to determine the risk of default of the borrowers and the transparency of the investment for creditors. To reduce the risk of credit default P2P platform usually offers loans to emerging marketplaces by linking interested borrowers and lenders via social networks. Urena, Kou, Dong, Chiclana, and Herrera-Viedma (2019) demarcated social networks as a platform of virtual interactions between people and services without any previous real-world relationship and interact sharing different kinds of information with the purpose of friendship, marketing or business exchange.

Despite the clear objective of P2P, it has created some issues for investors such as information asymmetry, inadequate credit assessment, and potential high default risk, which might have an impact on investors' intention to invest in P2P. Furthermore, risk assessment on loan is even more difficult in developing countries, due to the economic environment, lack of government regulations, information asymmetries and technological awareness among investors and borrowers (Dorfleitner, Oswald \& Zhang, 2019). Inadequate credit history limits the opportunity to distinguish high-risk borrowers from reliable ones or 
individual entrepreneurs with lower credit risk (Jenq, Pan \& Theseira, 2012). Those credit risks and information asymmetries can be minimized by collecting financial information through social networks. But using social networks also raises a critical question for investors/creditors, "how creditors can gain much-needed transparency on their investment by using social networks"?

In light of the foregoing, the problem statement for this study is that the lenders from developing countries faces a critical challenge where both the P2P platforms and their service tools or agents are not regulated by the government or protected by government agencies. As a result, lenders and borrowers may feel insecure.

Hence, the aim of this study is to demonstrate theoretically the factors that attract or influence the lenders (or investors) to invest through a P2P lending platform in a developing country and how information from social networks can be used as a tool to determine the credit risks associated with it. To achieve this, by benefiting from the social network theory propositions are developed to determine the inter-relations among P2P, perceived risks, security and social networks.

\section{LITERATURE REVIEW}

\section{The Demand for P2P Lending}

Why P2P lending is vital for individuals and society? Although various answers can be provided, one of the fundamental reasons is considered as its focus. Since the P2P platform does not only focus on the market for big loans but instead on the emerging markets that may require small loans, which banks generally do not consider due to high transaction costs (Freedman \& Jin, 2008), that makes the P2P utmost important for the individuals and the society. Furthermore, a high default rate increases the cost of capital requirements of the bank. Hence, banks always try to avoid lending to risky or unfamiliar borrowers who may bring cost on a reputation for traditional banks (Gabbi, Giammarino, Matthias, Monferrà \& Sampagnaro, 2020; Deli, Hasan \& Liu, 2019; Buckley \& Nixon, 2009). On other hand, the marginal costs on loans are relatively high for banks than P2P lending platforms which motivate the banks not to offer loans to the perilous borrowers, individuals, entrepreneurs, or small businesses (De Roure, Pelizzon \& Tasca, 2016). Such hassles lead potential borrowers to seek for P2P lending as an alternative financial source. 
According to Herrero-Lopez (2009) such platforms have at least two key benefits. First, it reduces the cost for borrowers, and second, it provides an investment opportunity for the individuals which can be led to potential economic development for a country. Grameen Bank in Bangladesh has proven that unprivileged groups benefited from "microcredit" ${ }^{1}$ financial invention, which allowed a priori non-bankable capitalists to contribute to self-employment ventures (Herrero-Lopez, 2009). Similarly, small businesses, new entrepreneurs, or less privileged people can access finance through P2P lending modality instead of regular methods of credit especially in developing countries like Bangladesh, India, China, Philippines, and etc. That can potentially reduce the negative effect of local informal moneylenders. P2P lending platforms always focus on democratizing the borrowers rather than discriminating them on their social or financial status (Herzenstein, Andrews, Dholakia \& Lyandres, 2008).

\section{Social Networks for Direct P2P}

Although there are no mediators to determine the creditworthiness and default risk in direct P2P, what are the factors that are critical in building social trust between lenders and borrowers? Milne and Parboteeah (2016) suggested four key factors for creating trust between the parties. First, direct P2P offers a higher return for the lenders and low cost for the borrowers compared to traditional banks as both cut the middleman. Second, it provides easy access to credit for the borrowers within a short period. Third, it provides social value addition to traditional banks. And as fourth, the utilization of innovative technologies using the mechanism of social networks is helpful in terms of speeding up the direct P2P lending.

In an attempt to promote and identify the creditable borrowers', direct P2P lending platforms like Prosper, Zopa, Lending Club use social networks and encourage the potential borrowers to provide the relevant financial information as much as possible throughout the social networks to reduce default risks (Ge, Feng \& Gu, 2016). Iyer, Khwaja, Luttmer, and Shue (2009) classified the infor-

1 According to Schroeder (2020) Economist Muhammad Yunus (founder of Grammen Bank of Bangladesh) termed Microcredit as a common form of microfinance that involves an extremely small loan given to an individual for self-employment projects, with the intention of allowing households that would otherwise be credit constrained to engage in income-generating activities. 
mation as "hard" and "soft", direct P2P platforms collect "hard" information like credit score, debt-to-income ratio, annual income as well as the business plan for utilizing the funds and "soft" information like a picture of the interested borrower through the social networks.

Thus, one may pose a question as "Do the social networks unravel the information asymmetry challenges of P2P lending for social capital"? The activity level and financial information provided on social media by the borrowers can act as predictors of their default probability (Freedman \& Jin, 2017; Ge et al., 2016). Direct P2P uses online social media such as Facebook, Instagram, LinkedIn, Twitter, WhatsApp, lending website, etc. or by an application that is developed by the lending platforms. The pictures of the proposed venture required primarily to evaluate borrower's creditworthiness as well as the potential for their business proposition (Bachmann et al., 2011). Research conducted by Wei and Lin (2016) identified that social media is also producing a significant amount of social network data that can be used as an instrument for credit scoring.

According to Bachmann et al. (2011) P2P lending platforms like Prosper.com encourage the members to form friendship networks and groups incorporate both current offline social contacts and newly created online friends or tapping on social capital. The capability to influence friendship networks during to place an online loan request to friends and to obtain notices of friends' borrowing and lending events is the main difference between online P2P lending platforms and traditional banking approaches (Bachmann et al., 2011). Freedman and Jin (2008) support that research as focusing on Prosper.com and its usage in terms of social networks for transactions and verification of provided financial information.

Experimental research on online social lending conducted by Everett (2019) reveals the risk of credit default will be lower if the location of the borrower is near to the other members of the group. Corresponding to social media disclosure by the potential borrower, the probability of getting a loan is high for the borrower with more friends, and the probability of loan default is lower (Lin, Prabhala \& Viswanathan, 2013). Research steered by Liu, Brass, Lu, and Chen (2015) on P2P lending in China also identified that friendship and group affect the economic decision of lenders as well as borrowers of P2P lending.

However, it is also difficult to ascertain the validity of the information that is provided in social media to select the creditworthy borrowers. Lin et al. (2013) emphasized that default risk is minimal when the P2P lending platform establishes a personal relationship with the borrowers. Similarly, Everett 
(2019) confirmed that a good relationship between borrowers and P2P lending reduces the chance of moral hazard issues.

\section{Social Networks for Indirect P2P}

Why indirect $\mathrm{P} 2 \mathrm{P}$ lending platforms are growing when potential borrowers can have easy access to direct $\mathrm{P} 2 \mathrm{P}$ through an online social network? Because indirect P2P models usually contribute to microcredit or crowdfunding ${ }^{2}$ through social networks to less privileged people (Uddin, Vizzari, Bandini \& Imam, 2018; Herrero-Lopez, 2009). Indirect P2P is needed for the poor who are not eligible to gain access to formal financial services due to missing access to financial security and technology skills, stable employment, and certifiable credit description (Bauchet, Marshall, Starita, Thomas \& Yalouris, 2011). Lender of indirect P2P gets only the loan principal or both principal amount and interest depend on the model of business strategy (Uddin et al., 2018). Indirect P2P like Rang De, Kiva, Zidisha, MyC4 operate lending activities via social networks where borrowers turn to the field partners or local financial institutions who works as a support system and appeals for a loan.

Hassett, Bergeron, Kreger, Looft, Allen, and Dubbe (2011) identified two types of indirect lending models: lending for-profit and not-for-profit. The authors argued that indirect P2P platforms can be considered as lending for-profit as well as not-for-profit or pro-social lending platforms. For example, MyC4 is an indirect P2P platform founded in 2006 as a for-profit (Dorfleitner et al., 2019; Bachmann et al., 2011). Wokaiis as another Chinese P2P lending platform also provides P2P lending for profit. Lenders of "for-profit platforms", receive a financial return from their socially motivated investment capital "Dutch auction" on the sites, where the cost of fund is reduced till a borrower is found.

Conversely, Jenq et at. (2012) identified Kiva as a not-for-profit P2P lending platform and found that Kiva operates through local microfinance institutions $(\mathrm{MFI})^{3}$, social enterprises, schools, and non-governmental organizations (NGOs) act as fields partners or intermediary agents between lenders and bor-

2 According to American business magazine Forbes (2018) “Crowdfunding is a process of raising a small amount of loan from large group of people typically through an online platform".

${ }^{3}$ Lam, Zhang, Ang, and Jacob (2020) defined Microfinance institutions (MFIs) as hybrid organizations with the dual mission of financial sustainability and social purpose. 
rowers in developing countries to improve the lives of the poor. Research by Zhao, Ge, Liu, Wang, Chen, and Zhang (2017) revealed that Kiva borrowers do not lend directly from the platforms but through field partners. According to Kiva.org individuals can lend as little as $\$ 25$ to create opportunities for borrowers and the platforms create revenues from donations, optional lender fees, and other sources. Kiva borrowers only need to repay the principal to lenders without any interest (Hartley, 2010) Field partners review the information, the purpose of the loan applications provided by the potential borrowers. Field Partners are also responsible for the disbursement and repayment collection of loans. If a loan is granted, the field partners post the borrower's profile information, picture, and purpose of the loan on Kiva. When Kiva delivers the fund to the local field partner, the field partner may require traveling to the borrower's location, such as the rural village, and collect a repayment regularly (Zhao et al., 2017).

Various factors influence or bias the lenders to lend through indirect P2P lending. Havrylchyk and Verdier (2018) identified the problem with indirect social P2P lending, where lenders do not receive any interest on their loans, and in fact, their capital is subject to default risk and exchange rate risk. As a result, full recovery of the loan is not assured because the intermediaries of the indirect P2P platforms do not promise or assure the full recovery of loans, which might discourage the lenders from participating in the platform.

\section{THEORETICAL FRAMEWORK}

This research identifies that transparency issue is one of the major factors that significantly affect the investor's intention and scope to participate in P2P lending whether it is a direct or indirect lending platform in a developing country.

\section{Perceived Risks and Trust}

Perceived risks ${ }^{4}$ and trust are deemed as ambiguity; often arise due to information or communication errors on financial transactions. Incapability to physical

4 Perceived risk is pertinent to intangible products or services that involved to online transaction. According to Featherman and Pavlou (2003), perceived risk is regarded as an unpredictability, with hostile or adverse implications, arising advance ques- 
inspection of direct P2P lending transactions is exposure to fraudulent activities. Meanwhile, the lack of inefficient infrastructure provided by the indirect P2P lending companies arise additional anxiety and fear of loss on investment (Manda \& Yamijala, 2019; Clarke, 2019). Research by Komiak and Benbasat (2006) revealed that if an individual user feels assured and secure about the validation of crowdfunding especially on P2P lending platforms trust will establish a positive relationship between lenders and borrowers. In an attempt to build trust and reputation among the users of the P2P lending platform is required to establish strong and reliable social networks to mitigate the trust issue and perceived institutional risks (Chen, Lai \& Lin, 2014).

Sukmaningsih (2018) suggested trust can be established among borrowers by offering full access to borrowers' information online, for example, photo, age, gender, national ID through social networks. Mohammadi and Broström (2018) disclosed that distrust is greatly correlated with larger amounts of loans, longer payment cycles, and greater geographical distance between lenders and borrowers. Scholars identified social networks are the key to formulate mutual trust, reciprocity, and to override any negative financial consideration for the lenders to participate in P2P lending platforms (Saeidi, 2020; Gonzalez, 2019). In this way, the first proposition is set forth as follows:

Proposition 1: The higher the trust on social networks, the lower the lender's perceived risks, hence, a higher chance to participate in P2P lending.

\section{Security}

Security is believed to be the most important element to develop an online transaction platform. Clients intentionally avoid online platforms which are exemplified by ambiguous information to secure financial information (Bertsch \& Rosenvinge, 2019; Urban, Amyx \& Lorenzon, 2009). Financial transactions by online P2P lending is a monetary fund, so it shares the same innate risks as other traditional financial activities, therefore social media or intermediaries of P2P platforms need highly sophisticated and reliable technology to guarantee the security of the lender's financial and personal information to protect their capital (Urban et at., 2009).

tion on purchasing commitment in terms of searching and choosing information for goods and services. 
The P2P lending face security-related issue such as the risk of securing the identity, financial information of investors as well as preventing money laundering and cyberattacks (Suryono, Purwandari \& Budi, 2019). These kinds of concerns especially arise in developing countries due to the lack of transparency and regulation by the government on the online transaction and investor protection compare to the traditional banking system. Šetlers and Valdmanis (2016) acknowledged that security standards of any transactional platform influence the behavior investors' decisions. To secure the transaction traditional banks recommend upgrading online services systems via pin code, mobile phone SMS, proof of verification, transaction passwords from the related bank, and one-time passwords from the user (Viriyarungsarit, 2017). Safety and security imply lenders' intuitions that lending through intermediary will satisfy such as authentication, quality, encryption, and nonrepudiation (Bokhari, 2019). Lenders will only seek to a P2P platform when they feel their capital will be securely the media or intermediates. The second proposition is formed on this basis as:

Proposition 2: The higher the security of social networks, the higher the safety of the lender's capital, hence a higher chance to participate in the P2P lending platform.

\section{a ConcLusion}

The growth of P2P lending platforms has been fueled due to the lending restriction from traditional financial institutions. SMEs and individual entrepreneurs can utilize P2P lending as a unique alternate financing method. However, P2P lending platforms are facing information asymmetry issues that are collected through social networks, especially in a developing country. This research aims to demonstrate theoretically the factors that influence lenders to invest in the P2P lending platform in developing countries.

Several social network literatures offer support for the important role of the social network to mitigate risks for P2P lenders such as in achieving transparency in terms of better borrower selection, lending, and default risk. This approach is based on the changing nature of perceived risk and the security of the lender's capital relations. The propositions of this study demonstrate that with a higher level of trust on social networks, the lenders can lower their perceived risks, hence, providing a better chance for them to participate in P2P lending. 
However, by creating a more secure social network for the P2P lenders and borrowers, a higher level of safety for the lender's capital can be ensured.

In bringing the social network approach to determine the benefits and risks of P2P lending, we aim to draw attention to the trust-risk nexus within the context of P2P lending. However, the limitations of the study should not be left overlooked; specifically, the topics related to the legal and regulatory framework should also be considered since the power relationship for lenders and borrowers may change. Moreover, the propositions/results may differ when it comes to different country settings with distinct socio-economic conditions (in terms of level of development), the role of the state in the economy including robust regulatory framework and the effect of culture on perceived risk for P2P lending may also be considered in future studies. The two theoretical propositions put forth in this study can be further tested in terms of validity through empirical analysis of data collected from surveys and perhaps Randomized Control Trials (RCTs).

\section{REFERENCES}

Ariza, M., Arroyo, J., Caparrini, A., \& Segovia, M.J. (2020). Explainability of a Machine Learning Granting Scoring Model in Peer-to-Peer Lending. IEEE Access, 8, 6487364890. http://dx.doi.org/10.1109/ACCESS.2020.2984412.

Bachmann, A., Becker, A., Buerckner, D., Hilker, M., Kock, F., Lehmann, M., Tiburtius, P., \& Funk, B. (2011). Online peer-to-peer lending-a literature review. Journal of Internet Banking and Commerce, 16(2), 1-18.

Balyuk, T. (2019). Financial innovation and borrowers: Evidence from peer-to-peer lending. Rotman School of Management Working Paper, 2802220, 1-56. http://dx.doi. org/10.2139/ssrn.2802220.

Bauchet, J., Marshall, C., Starita, L., Thomas, J., \& Yalouris, A. (2011). Latest findings from randomized evaluations of microfinance. Washington: World Bank.

Bertsch, C., \& Rosenvinge, C.J. (2019). FinTech credit: Online lending platforms in Sweden and beyond. Sveriges Riksbank Economic Review, 2, 42-70.

Bokhari, M.M. (2019). Credit Risk Analysis in Peer to Peer Lending Data set: Lending Club. Senior Projects Spring, 105, 1-48.

Buckley, R.P., \& Nixon, J. (2009). The role of reputation in banking. Journal of Banking and Finance Law and Practice, 20, 37-50.

Chen, D., Lai, F., \& Lin, Z. (2014). A trust model for online peer-to-peer lending: a lender's perspective. Information Technology and Management, 15(4), 239-254. http://dx.doi. org/10.1007/s10799-014-0187-z.

Chen, X., Chong, Z., \& Giudici, P. (2020). Networking with Peers: Evidence from a P2P Lending Platform. ADBI Working Paper, 1080, 1-46. 
Clarke, C. (2019). Platform lending and the politics of financial infrastructures. Review of International Political Economy, 26(5), 863-885. http://dx.doi.org/10.1080/0969 2290.2019.1616598.

De Roure, C., Pelizzon, L., \& Tasca, P. (2016). How does P2P lending fit into the consumer credit market? Discussion Paper Deutsche Bundesbank, 30/2016, 1-19.

Deli, Y. D., Delis, M.D., Hasan, I., \& Liu, L. (2019). Enforcement of banking regulation and the cost of borrowing. Journal of Banking \& Finance, 101, 147-160. http://dx.doi. org/10.1016/j.jbankfin.2019.01.016.

Dorfleitner, G., Oswald, E.M., \& Zhang, R. (2019). From credit risk to social impact: On the funding determinants in interest-free peer-to-peer lending. Journal of Business Ethics, 1-26. http://dxdoi.org/10.1007/s10551-019-04311-8.

Du, N., Li, L., Lu, T., \& Lu, X. (2020). Prosocial Compliance in P2P Lending: A Natural Field Experiment. Management Science, 66(1), 315-333.

Everett, C.R. (2019). Origins and development of credit-based crowdfunding. Graziadio Working Paper Series, 7, 1-32.

Featherman, M.S., \& Pavlou, P.A. (2003). Predicting e-services adoption: a perceived risk facets perspective. International journal of human-computer studies, 59(4), 451-474. http://dx.doi.org/10.1016/S1071-5819(03)00111-3.

Forbes (2018). What Is Crowdfunding? https://www.forbes.com/sites/devinthorpe/2018/06/25/what-is-crowdfunding/\#696c673465c5.

Freedman, S., \& Jin, G.Z. (2008). Do social networks solve information problems for peer-to-peer lending? Evidence from Prosper. com. NET Institute Working Paper, \#08-43, 1-63.

Freedman, S., \& Jin, G.Z. (2017). The information value of online social networks: lessons from peer-to-peer lending. International Journal of Industrial Organization, 51, 185-222. http://dx.doi.org/10.1016/j.ijindorg.2016.09.002.

Gabbi, G., Giammarino, M., Matthias, M., Monferrà, S., \& Sampagnaro, G. (2020). Does face-to-face contact matter? Evidence on loan pricing. The European Journal of Finance, 26(7-8), 820-836. http://dx.doi.org/10.1080/1351847X.2019.1703023.

Ge, R., Feng, J., \& Gu, B. (2016). Borrower's default and self-disclosure of social media information in P2P lending. Financial Innovation, 2(30), 1-6. http://dx.doi. org/10.1186/s40854-016-0048-3.

Gonzalez, L. (2019). Blockchain, herding, and trust in peer-to-peer lending. Managerial Finance, 46(6), 815-831. http://dx.doi.org/10.1108/MF-09-2018-0423.

Hartley, S.E. (2010). Kiva.org: Crowd-sourced microfinance and cooperation in group lending. SSRN Working Paper, 1572182. http://dx.doi.org/10.2139/ssrn.1572182.

Hassett, T., Bergeron, J., Kreger, M., Looft, M., Allen, G., \& Dubbe, D. (2011). Indirect P2P platforms. Global Microcredit Summit, 1-32.

Havrylchyk, 0., \& Verdier, M. (2018). The financial intermediation role of the P2P lending platforms. Comparative Economic Studies, 60(1), 115-130. http://dx.doi. org/10.1057/s41294-017-0045-1.

Herrero-Lopez, S. (2009). Social interactions in P2P lending. In C.L. Giles, P. Mitra, I. Perisic, J. Yen, H. Zhang (Eds.). SNA-KDD '09: Proceedings of the 3rd Workshop on 
Social Network Mining and Analysis. New York: Association for Computing Machinery. http://dx.doi.org/10.1145/1731011.1731014.

Herzenstein, M., Andrews, R.L., Dholakia, U.M., \& Lyandres, E. (2008). The democratization of personal consumer loans? Determinants of success in online peer-to-peer lending communities. Boston University School of Management Research Paper, 14(6), $1-36$.

Iyer, R., Khwaja, A. I., Luttmer, E. F., \& Shue, K. (2009). Screening in new credit markets: Can individual lenders infer borrower creditworthiness in peer-to-peer lending? AFA 2011 Denver Meetings Paper, 1-41. http://dx.doi.org/10.2139/ssrn.1570115.

Iyer, R., Khwaja, A.I., Luttmer, E.F., \& Shue, K. (2016). Screening peers softly: Inferring the quality of small borrowers. Management Science, 62(6), 1554-1577. http:// dx.doi.org/10.1287/mnsc.2015.2181.

Jenq, C., Pan, J., \& Theseira, W. (2012). What do donors discriminate on? Evidence from kiva.org, http://editorialexpress.com/cgi-bin/conference/download.cgi?db_ name $=$ SERC2011\&paper_id $=310$.

Komiak, S.Y., \& Benbasat, I. (2006). The effects of personalization and familiarity on trust and adoption of recommendation agents. MIS Quarterly, 30(4), 941-960.

Lam, S.S., Zhang, W., Ang, A.X., \& Jacob, G.H. (2020). Reciprocity Between Financial and Social Performance in Microfinance Institutions. Public Performance \& Management Review, 43(1), 206-231. http://dx.doi.org/10.1080/15309576.2019.1604386.

Lin, M., Prabhala, N.R., \& Viswanathan, S. (2013). Judging borrowers by the company they keep: Friendship networks and information asymmetry in online peerto-peer lending. Management Science, 59(1), 17-35. http://dx.doi.org/10.1287/ mnsc.1120.1560.

Liu, D., Brass, D., Lu, Y., \& Chen, D. (2015). Friendships in online peer-to-peer lending: Pipes, prisms, and relational herding. MIS Quarterly, 39(3), 729-742.

Manda, V.K., \& Yamijala, S.P. (2019). Peer-to-Peer Lending using BlockChain. Advance and Innovative Research, 6, 61-66.

Milne, A., \& Parboteeah, P. (2016). The business models and economics of peer-to-peer lending. ECRI Research Report, 17, 1-36.

Mohammadi, A., \& Broström, A. (2018). Distrust in financial institutions and fintech adoption: The case of P2P loans. Paper presented at DRUID18, Copenhagen Business School, Copenhagen, Denmark, June 11-13, 2018, http://conference.druid.dk/ acc_papers/ixxsns2rjntpw9cwmz1qkcimxlf26i.pdf.

Paravisini, D., Rappoport, V., \& Ravina, E. (2017). Risk aversion and wealth: Evidence from person-to-person lending portfolios. Management Science, 63(2), 279-297.

Saeidi, S. (2020). A new model for calculating the maximum trust in Online Social Networks and solving by the Artificial Bee Colony algorithm. Computational Social Networks, 7(3), 1-21. http://dx.doi.org/10.1186/s40649-020-00077-6.

Schroeder, E. (2020). The impact of microcredit borrowing on household consumption in Bangladesh. Applied Economics, 52(43), 4765-4779. http://dx.doi.org/10.1080/00 036846.2020.1743815. 
Šetlers, G., \& Valdmanis, J. (2016). Crowdlending: Factors driving investors' decisionmaking in Latvia. SSE Riga Student Research Papers, 1(177), 1-49.

Sukmaningsih, D.W. (2018). A model for lender-borrower trust in peer-to-peer lending. ComTech: Computer, Mathematics and Engineering Applications, 9(1), 15-24. http:// dx.doi.org/10.21512/comtech.v9i1.4287.

Suryono, R.R., Purwandari, B., \& Budi, I. (2019). Peer to Peer (P2P) Lending Problems and Potential Solutions: A Systematic Literature Review. Procedia Computer Science, 161, 204-214. http://dx.doi.org/10.1016/j.procs.2019.11.116.

Uddin, M.J., Vizzari, G., Bandini, S., \& Imam, M.O. (2018). A case-based reasoning approach to rate microcredit borrower risk in online Kiva P2P lending model. Data Technologies and Applications, 52(1), 58-83. http://dx.doi.org/10.1108/DTA-022017-0009.

Urban, G. L., Amyx, C., \& Lorenzon, A. (2009). Online trust: State of the art, new frontiers, and research potential. Journal of Interactive Marketing, 23(2), 179-190. http:// dx.doi.org/10.1016/j.intmar.2009.03.001.

Urena, R., Kou, G., Dong, Y., Chiclana, F., \& Herrera-Viedma, E. (2019). A review on trust propagation and opinion dynamics in social networks and group decision-making frameworks. Information Sciences, 478, 461-475. http://dx.doi.org/10.1016/j. ins.2018.11.037.

Viriyarungsarit, S. (2017). Bank of the year 2017. Money and Banking Magazine, 35, 24-28.

Wei, Z., \& Lin, M. (2016). Market mechanisms in online peer-to-peer lending. Management Science, 63(12), 4236-4257. http://dx.doi.org/10.1287/mnsc.2016.2531.

Zhao, H., Ge, Y., Liu, Q., Wang, G., Chen, E., \& Zhang, H. (2017). P2P lending survey: platforms, recent advances, and prospects. ACM Transactions on Intelligent Systems and Technology (TIST), 8(6), 1-28. http://dx.doi.org/10.1145/3078848. 